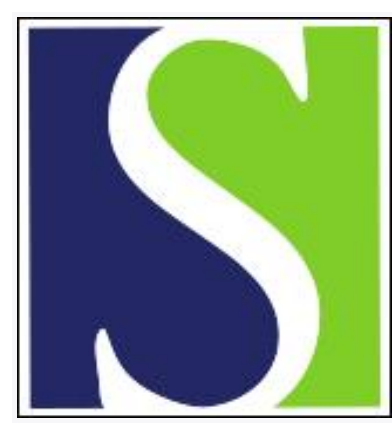

Scand J Work Environ Health 1994;20(6):459-465

https://doi.org/10.5271/sjweh.1374

Issue date: 01 Dec 1994

Exposure-response relationships in the formation of specific antibodies to hexahydrophthalic anhydride in exposed workers.

by Welinder HE, Jonsson BA, Nielsen JE, Ottosson HE, Gustavsson CA

Affiliation: Department of Occupational and Environmental Medicine, University Hospital, Lund, Sweden.

This article in PubMed: www.ncbi.nlm.nih.gov/pubmed/7701292

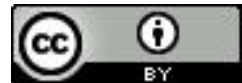




\title{
Exposure-response relationships in the formation of specific antibodies to hexahydrophthalic anhydride in exposed workers
}

\author{
by Hans $\mathrm{E}$ Welinder, PhD, Bo AG Jönsson, PhD, Jörn E Nielsen, MD, Helene E Ottosson, \\ Cecilia A Gustavsson, BSc ${ }^{1}$
}

\begin{abstract}
WELINDER HE, JÖNSSON BAG, NIELSEN JE, OTTOSSON HE, GUSTAVSSON CA. Exposureresponse relationships in the formation of specific antibodies to hexahydrophthalic anhydride in exposed workers. Scand J Work Environ Health 1994;20:459-65.
\end{abstract}

\begin{abstract}
OBJEctives - Exposure-response relationships in the formation of specific antibodies to hexahydrophthalic anhydride (HHPA) was studied in exposed workers.

METHODs - The relation between exposure to HHPA and the levels of specific immunoglobin E [(radioallergosorbent test (RAST)] and immunoglobin G (enzyme-linked immunosorbent assay) antibodies was investigated in a cross-sectional study on 95 workers from two plants using epoxy resin with HHPA as a hardener; the mean time of exposure was 7 (range $0.1-25$ ) years.

Results - The specific immunoglobin E and immunoglobin $G$ was significantly increased in exposed workers when they were compared with unexposed workers or external referents. There was no significant difference in the number of RAST positives $[\mathrm{N}=23(24 \%)]$ between the groups of workers exposed to $<10 \mu \mathrm{g} \cdot \mathrm{m}^{-3}, 10-<50 \mu \mathrm{g} \cdot \mathrm{m}^{-3}$, or $\geq 50 \mu \mathrm{g} \cdot \mathrm{m}^{-3}$. No effects were found of atopy or smoking habits on the prevalence of RAST positives. Five out of seven workers positive for immunoglobulin $\mathrm{E}$ in the group with the lowest exposures reported frequent short-time (minutes per day) exposures exceeding $50 \mu \mathrm{g} \cdot \mathrm{m}^{-3}$. A correlation was seen between specific immunoglobulin $\mathrm{E}$ and $\mathrm{G}$ antibodies $\left(r_{s}=0.5\right)$.

Conclusions - The results indicate that HHPA is a sensitizing compound even at low exposure levels and that short-time peak exposures may have an impact on immunoglobulin $\mathrm{E}$ sensitization.
\end{abstract}

KEY TERMS -- analysis, epoxy resin, exposure levels, specific immunoglobulin E, specific immunoglobulin G.

Safe use of substances potentially causing allergic respiratory diseases in industry demands studies on exposure-response relationships. Studies on factors leading to sensitization have been more focused on individual predisposing factors such as atopy and smoking habits and not on exposure levels $(1-4)$. Thus knowledge on the exposure levels necessary for sensitization is limited. Occupational allergens offer unique possibilities to study exposure-response relationships for allergic respiratory tract diseases.

Acid anhydrides form a group of industrially important, low-molecular weight, reactive organic molecules causing sensitization of the respiratory tract. Specific serum immunoglobulin (Ig) E antibodies have been found in exposed workers, and they indicate the existence of an IgE-mediated mechanism (5-7). The prevalence of specific IgE antibodies may be high, up to $40-50 \%$, in exposed groups (811). Specific IgG antibodies have been associated with a late respiratory systemic syndrome (12). These

Department of Occupational and Environmental Medicine, University Hospital, Lund, Sweden.

Reprint requests to: Dr H Welinder, Department of Occupational and Environmental Medicine, University Hospital, S-22 185 Lund, Sweden. characteristics make the acid anhydrides an interesting model for the study of exposure-response relationships in occupational airway diseases. Exposure data that can be related for anhydrides to different measures of response are scant and sometimes not reliable $(5,6)$. Exposure-response investigations providing data upon which occupational exposure limits can be based are few. A study on workers exposed to methyltetrahydrophthalic anhydride (MTHPA) (13) showed a high frequency of work-related symptoms even at surprisingly low exposure levels. The frequency of specific $\operatorname{IgE}$ antibodies was $16 \%$ even at exposures below $20 \mathrm{mg} \cdot \mathrm{m}^{-3}$. These findings motivate further studies on structurally related anhydrides. In the present investigation, the relation between exposure and the levels of specific $\operatorname{IgE}$ and IgG antibodies in workers exposed to hexahydrophthalic anhydride (HHPA) in two different plants are presented.

\section{Subjects and methods}

\section{Production and exposure}

Plant A. Plant A produces components for the electronics industry, mainly ignition systems. The components are mechanically fixed and electrically iso- 
lated in epoxy resin. An epoxy resin with acid anhydrides as a hardener has been used since 1972 . The main component in the hardener is HHPA, but methylhexahydrophthalic anhydride (MHHPA) has also been used to a minor extent for vacuum impregnation and as an added ingredient to HHPA. The components are finally cured at temperatures of 90 $140^{\circ} \mathrm{C}$. The main exposure originates from casting and from leaks from the curing ovens. Measurements of the HHPA and MHHPA levels in the air have been performed since 1989. (See figure 1 for the chemical structures of HHPA and MHHPA.)

Plant B. Plant B produces electrical capacitors isolated by epoxy resin using mainly HHPA, but also MHHPA, as a hardener. The epoxy system has been used since 1964. In this plant the main exposure also originates from casting and from leaks from the curing ovens. Measurements of HHPA levels in the air have been performed since 1989. MHHPA has been measured since 1991.

\section{Subjects}

In plant $A$ all of the subjects occupied with tasks in the two casting departments were investigated in June 1989. Altogether 12 persons (four women) were investigated. In plant B all of the persons in the two casting departments were investigated during 1989 and 1990. From the departments outside the casting departments, but in the close vicinity, all workers $(\mathrm{N}=20)$ were included from one department, and 17 persons were randomly selected from a second department. These people mainly mounted capacitors before and after casting. However, 22 of these workers had intermittently peak exposures to levels above $50 \mu \mathrm{g} \cdot \mathrm{m}^{-3}$ when entering the casting departments to deliver and collect materials. Altogether 83 exposed persons (women $43 \%$ ) were investigated. Twenty-six persons (group 0; women 35\%) were selected from plant B as an internal reference group representing workers with no known exposure to the epoxy system. The mean exposure time for the 95 exposed workers was 7 (range $0.1-25$ ) years.

A history of atopy and smoking habits was obtained by a physician (JN) during a detailed interview. A subject was defined as an atopic when he had a history of hay fever, asthma, atopic eczema, or urticaria (when the history of a relation to a particular agent was convincing) during childhood or adolescence.

The workers in plants A and B were pooled and separated into three different exposure categories according to the results of the HHPA and MHHPA measurements. Group 1 was composed of persons working outside the casting departments and exposed at mean levels of $<10 \mu \mathrm{g} \cdot \mathrm{m}^{-3}$. In group 2 the workers were exposed at a mean level of 10$<50 \mu \mathrm{g} \cdot \mathrm{m}^{-3}$, and group 3 was composed of workers exposed to uncured resins at mean exposure levels of $\geq 50 \mu \mathrm{g} \cdot \mathrm{m}^{-3}$. The number of workers exposed to MHHPA was $29(30 \%, 12$ from plant $A$ and 17 from plant B). Twenty-one belonged to group 2 and eight to group 1 .

External referents ( 54 persons, $39 \%$ women) were obtained from food industries situated near plant B. In this group there was no history of acid anhydride exposure.

The workers were of the same age in the different groups, and there was no statistically significant difference in the time of exposure between the different groups (table 1).

\section{Hexahydrophthalic anhydride in air}

Air samples were collected on amberlite XAD-2 tubes (no 226-30, SKC Inc, Eighty Four, Pennsylvania, United States) by personal sampling in the breathing zone of the workers and by area sampling with battery-operated pumps. The sampling was performed during 1989-1990. The sampling rate was $0.2-1.01 \cdot \mathrm{min}^{-1}$, and the sampling volume was 4 55 1. HHPA and MHHPA were desorbed by $1 \mathrm{ml}$ of toluene. The anhydrides were analyzed by capillary gas chromatography with flame-ionization detection $(14,15)$. Briefly, with the use of a Varian 3500 gas chromatographic system (Palo Alto, California, United States), $1 \mu$ l of the toluene solution was injected into a CP-sil $8 \mathrm{CB}$ column, $25 \mathrm{~m} \times$ $0.25 \mathrm{~mm}$ inner diameter and $0.25 \mu \mathrm{m}$ film thickness. The limit of detection was $0.1 \mu \mathrm{g} \mathrm{HHPA} \cdot \mathrm{ml}$ toluene $\mathrm{e}^{-1}$, corresponding to $5 \mu \mathrm{g} \cdot \mathrm{m}^{-3}$ at a sampling volume of 201.

Air HHPA levels of up to $470 \mu \mathrm{g} \cdot \mathrm{m}^{3}$ were found in personal samples in the breathing zone of work-

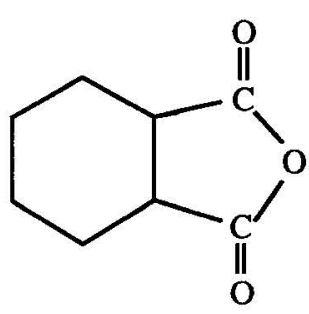

HHPA

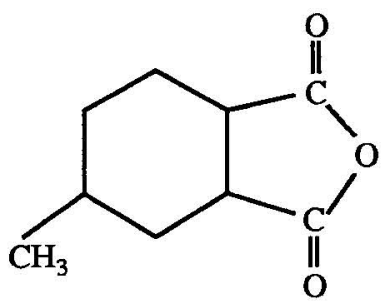

MHHPA
Figure 1. Chemical structures of hexahydrophthalic anhydride (HHPA) and methylhexahydrophthalic anhydride (MHHPA). 
Table 1. Age, exposure level, and length of exposure to hexahydrophthalic anhydride (HHPA) in different exposure categories of workers exposed to HHPA and in a reference group.

\begin{tabular}{|c|c|c|c|c|c|c|}
\hline & \multirow{2}{*}{$\begin{array}{c}\text { Number } \\
\text { of } \\
\text { workers }\end{array}$} & \multicolumn{2}{|c|}{ Age (years) } & \multirow{2}{*}{$\begin{array}{c}\text { Exposure } \\
\text { level } \\
\left(\mu \mathrm{g} \cdot \mathrm{m}^{-3}\right)\end{array}$} & \multicolumn{2}{|c|}{$\begin{array}{l}\text { Length of exposure } \\
\text { (years) }\end{array}$} \\
\hline & & Mean & Range & & Mean & Range \\
\hline Group 0 & 26 & 32 & $19-63$ & 0 & $5.0^{\mathrm{a}}$ & $0.5-22$ \\
\hline Group $1^{\mathrm{b}}$ & 37 & 34 & $20-62$ & $<10$ & 6.0 & $0.1-25$ \\
\hline $\begin{array}{l}\text { Intermittent peak exposure } \\
\text { No intermittent peak exposure }\end{array}$ & $\begin{array}{l}19 \\
15\end{array}$ & $\begin{array}{l}41 \\
28\end{array}$ & $\begin{array}{l}20-61 \\
20-62\end{array}$ & $\begin{array}{l}<10 \\
<10\end{array}$ & $\begin{array}{c}10 \\
2.5\end{array}$ & $\begin{array}{l}1.5-25 \\
0.1-20\end{array}$ \\
\hline Group 2 & 32 & 33 & $19-64$ & $10-<50$ & 3.5 & $0.2-25$ \\
\hline Group 3 & 26 & 35 & $20-62$ & $\geq 50$ & 5.5 & $0.1-20$ \\
\hline Referents & 54 & 33 & $20-61$ & . & . & $\cdot$ \\
\hline
\end{tabular}

a Time of employment.

b Three subjects with an earlier history of exposure $>10 \mu \mathrm{g} \cdot \mathrm{m}^{-3}$ were omitted from the data on workers in group 1 with and without intermittent peak exposure.

ers in the casting departments. The mean levels of the sum of HHPA and MHHPA in the casting departments in plant A were 82 and $33 \mu \mathrm{g} \cdot \mathrm{m}^{-3}$, respectively, and the corresponding values of HHPA in plant B were 140 and $35 \mu \mathrm{g} \cdot \mathrm{m}^{-3}$, respectively. The different levels were governed by differences in the automatization levels and by differences in the functions of the ovens. The mean level of HHPA in the involved departments in plant $B$ just outside the casting departments was $4 \mu \mathrm{g} \cdot \mathrm{m}^{-3}$. In plant $\mathrm{A}$, MHHPA composed $38 \%$ of the anhydride exposure (table 2 ). In plant B the MHHPA exposure was restricted to casting department 2. Measurements performed in 1991 showed a MHHPA mean level of $4 \mu \mathrm{g} \cdot \mathrm{m}^{-3}$ (personal sampling; $\mathrm{N}=15$ ), when the corresponding HHPA level was $11 \mu \mathrm{g} \cdot \mathrm{m}^{-3}$ (Welinder, to be published).

\section{Antibody determinations}

The antibody determinations were performed according to procedures which have been described and validated earlier $(10,16)$.

Antigen. A hapten conjugate was prepared from HHPA (Ciba-Geigy AB, Basel, Switzerland) and human serum albumin (HSA) (Kabi, Stockholm, Sweden); HHPA was added to a cooled solution of $300 \mathrm{mg}$ of HSA $\left(37 \mathrm{~mol} \cdot \mathrm{mol}^{-1}\right)$ in $100 \mathrm{ml}$ of $0.1 \mathrm{M}$ of sodium hydrogen carbonate $\left(\mathrm{NaHCO}_{3}\right)$. The protein was purified from low-molecular weight compounds $(<30000 \mathrm{da})$ by filtration in an Amicon ultra filtration cell (8200, Amicon Corporation, Danvers, Massachusetts, United States). The protein was lyophilized and reconstituted in $0.1 \mathrm{M} \mathrm{NaHCO}_{3}$ when used.

Specific immunoglobulin $E$ antibodies. The HHPAHSA conjugate was bound to filter-paper discs activated by cyanogen bromide for use in the radioallergosorbent test (RAST). We used the Phadebas
Table 2. Exposure levels (mean and range) of hexahydrophthalic anhydride (HHPA) and methylhexahydrophthalic anhydride (MHHPA) at personal sampling in different parts of the plants.

\begin{tabular}{|c|c|c|c|c|c|}
\hline & \multirow{2}{*}{$\begin{array}{l}\text { Samples } \\
(N)\end{array}$} & \multicolumn{2}{|c|}{$\begin{array}{c}\mathrm{HHPA} \\
\left(\mu \mathrm{g} \cdot \mathrm{m}^{-3}\right)\end{array}$} & \multicolumn{2}{|c|}{$\begin{array}{c}\text { MHHPA } \\
\left(\mu \mathrm{g} \cdot \mathrm{m}^{-3}\right)\end{array}$} \\
\hline & & Mean & Range & Mean & Range \\
\hline \multicolumn{6}{|l|}{ Plant A } \\
\hline $\begin{array}{l}\text { Casting department } 1 \\
\text { Casting department } 2\end{array}$ & $\begin{array}{l}21 \\
18\end{array}$ & $\begin{array}{l}33 \\
23\end{array}$ & $\begin{array}{c}14-131 \\
2-98\end{array}$ & $\begin{array}{r}48 \\
9\end{array}$ & $\begin{array}{l}6-403 \\
2-30\end{array}$ \\
\hline \multicolumn{6}{|l|}{ Plant B } \\
\hline $\begin{array}{l}\text { Casting department } 1 \\
\text { Casting department } 2 \\
\text { Mixed work } \\
\text { Mounting }\end{array}$ & $\begin{array}{r}58 \\
13 \\
7 \\
26\end{array}$ & $\begin{array}{r}140 \\
35 \\
15 \\
4\end{array}$ & $\begin{array}{l}3-470 \\
2-210 \\
7-27 \\
2-9\end{array}$ & $\dot{.}$ & $\dot{.}$ \\
\hline
\end{tabular}

RAST system (Pharmacia Diagnostics AB, Uppsala, Sweden), according to the standard procedure, using $50 \mu \mathrm{l}$ of serum and $50 \mu \mathrm{l}$ of $\operatorname{IgE}^{125}$ I solution. All of the samples were analyzed in duplicate. The results were expressed as the percentage of specific binding (counts per minute of the test disc - counts per minute of the HSA reference disc) of total added radioactivity.

Specific immunoglobulin $G$ antibodies. Specific $\operatorname{IgG}$ antibodies to HHPA-HSA were analyzed by enzymelinked immunosorbent assay (ELISA). Wells of polystyrene microtiter plates (Nunc-lmmuno Plate 1, Nunc, Kamstrup, Denmark) were coated by the addition of $100 \mu \mathrm{l}$ of the antigen solution. The plates were stored with blocking solution at $-18^{\circ} \mathrm{C}$. All of the washings were performed by a Titertek Microplate Washer (Flow Laboratories, Irvine, United Kingdom). The analytical procedure was as follows: (i) addition of $100 \mu \mathrm{l}$ of a 1:50 dilution (phosphate buffered saline) of serum, (ii) incubation for $60 \mathrm{~min}$ at $20^{\circ} \mathrm{C}$, (iii) addition of $100 \mu \mathrm{l}$ of an optimal dilution (1:2000) of rabbit antihuman IgG conjugated with alkaline phosphatase (Dakopatts, Copenhagen, Denmark), (iv) incubation for $60 \mathrm{~min}$ at $20^{\circ} \mathrm{C}$, (v) addition of $100 \mu \mathrm{l}$ substrate solution (disodium p-ni- 
trophenol phosphate), and (vi) incubation for $120 \mathrm{~min}$ at $20^{\circ} \mathrm{C}$. The results were read at $405 \mathrm{~nm}$ (TitertekMultiscan, Eflab Oy, Helsinki, Finland). All of the samples were analyzed in triplicate. The results have been expressed as the absorbance value (A).

\section{Statistical methods}

Spearman's rank-correlarion statistic was used for testing the association between the pairs of variables. For comparisons of distributions between different groups, the Mann-Whitney U test was used. All of the P-values were two-tailed; "statistically significant" refers to $\mathrm{P}<0.05$.

\section{Results}

\section{Antibody findings}

There was a significant increase in the levels of specific IgE antibodies to HHPA-HSA between the exposed workers (group 1-3) and the referents $(P=0.0001)$ (table 3). The increase was statistically significant in all of the exposed groups (group 1: $\mathrm{P}=0.002$, group 2: $\mathrm{P}=0.0001$, group $3: \mathrm{P}=0.0002$ ), but not in the unexposed (group 0 ) in comparison with the referents. There were no significant differences in the RAST values between exposed groups 1 through 3, but all of the groups of exposed workers had significantly increased levels compared with those of the unexposed group (group 0). When the workers in group 1 with intermittent peak exposures at $>50 \mu \mathrm{g} \cdot \mathrm{m}^{-3}(\mathrm{~N}=19)$ were compared with the rest of the workers in group $1(\mathrm{~N}=15)$, the intermittently exposed ones had significantly higher levels of specific IgE antibodies $(P=0.005)$. There was no significant difference between the workers only exposed to levels $<10 \mu \mathrm{g} \cdot \mathrm{m}^{-3}$ and the referents. A high correlation was found between IgE antibodies to HHPAHSA and MHHPA-HSA ( $r=0.94)$.

No correlation was seen between specific IgE antibodies and time of exposure. A correlation between serum levels of total IgE and specific IgE to HHPAHSA was significant but not strong $\left(r_{\mathrm{s}}=0.3\right)$.
The RAST values for the 54 referents were in the range of $0.0-0.2 \%$ binding; values of $>0.3$ were regarded as positive. There was no statistically significant difference in the fraction of RAST positive workers between exposed groups 1 through 3 . All of the unexposed workers from plant B were negative, even those with a high level of total $\operatorname{IgE}$ antibodies (table 3). The median exposure time for HHPA in IgE-HHPA-HSA positive workers was 4 (range $0.3-22$ ) years. Three workers with an exposure time of less than one year were positive for specific IgE antibodies. The exposure time did not differ between specific IgE positive and negative workers. In group 1 , five out of seven positive workers reported frequent short-time exposures to $>50 \mu \mathrm{g} \cdot \mathrm{m}^{-3}$. The peak exposure time varied between $5 \mathrm{~min}$ a week and 15 min a day. The other two specific IgE-positive workers reported a history of earlier exposure to higher levels of HHPA. The total IgE levels were significantly increased $(\mathrm{P}=0.001)$ in the RAST positive workers.

Four $(17 \%)$ of the specific IgE positive workers $(\mathrm{N}=23)$ were atopics compared with eight $(11 \%)$ of the IgE negative workers $(\mathrm{N}=73)$. The corresponding figures for smoking habits were $39 \%$ (ex-smokers $26 \%$ ) and $53 \%$ (ex-smokers $17 \%$ ), respectively. The differences were not statistically significant.

The level of specific IgG antibodies to HHPAHSA was increased in the exposed workers (groups $1-3, \mathrm{P} \leq 0.003)$, as well as in group $2(\mathrm{P}<0.001)$, and group $3(P=0.0001)$, compared with the unexposed workers (group 0 ) and the referents, respectively. No significant difference was found between group 1 and the referents. When the IgG levels in the different exposed groups were compared, the levels were significantly higher in group $3(\mathrm{P}=0.0001)$ and group $2(\mathrm{P}=0.003)$ than in group 1 . A correlation was found between specific IgE and IgG antibodies $(r=0.5)$.

Significantly more subjects in groups 2 and 3 were positive to specific antibodies of the IgG type to HHPA-HSA than in the other groups (table 3 ). Values above 0.23 (upper limit of the referents) were regarded as positive. The $\operatorname{IgE}$ positive workers had

Table 3. Immunoglobulin ( $\mathrm{g}) \mathrm{E}$ and $\mathrm{G}$ levels and the number of persons with specific antibodies to a hapten conjugate of hexahydrophthalic anhydride and human serum albumin (HHPA-HSA) in different exposure categories of workers exposed to HHPA and in a reference group.

\begin{tabular}{|c|c|c|c|c|c|c|c|c|c|c|c|}
\hline & \multirow{2}{*}{$\begin{array}{c}\text { Number } \\
\text { of } \\
\text { workers }\end{array}$} & \multicolumn{2}{|c|}{$\begin{array}{c}\text { Total lgEa } \\
\text { (kUII) }\end{array}$} & \multicolumn{2}{|c|}{$\begin{array}{l}\text { Specific lgE } \\
\text { (\% binding) }\end{array}$} & \multicolumn{2}{|c|}{$\begin{array}{l}\text { Positive } \\
\text { for lgE }\end{array}$} & \multicolumn{2}{|c|}{$\begin{array}{l}\text { Specific IgG } \\
\text { (A) }\end{array}$} & \multicolumn{2}{|c|}{ Positive IgG } \\
\hline & & Median & Range & Median & Range & $N$ & $\%$ & Median & Range & $N$ & $\%$ \\
\hline Group 0 & 26 & 38 & $1-495$ & 0.0 & $0.0-0.1$ & - & 0 & 0.02 & $0.00-0.19$ & - & 0 \\
\hline Group 1 & 37 & 21 & $1-427$ & 0.1 & $0.0-7$ & 7 & 19 & 0.03 & $0.0-0.5$ & 3 & 8 \\
\hline $\begin{array}{l}\text { Intermittent } \\
\text { peak exposure }\end{array}$ & 19 & 24 & $2-427$ & 0.2 & $0.0-7.4$ & 5 & 26 & 0.03 & $0-0.5$ & 2 & 10 \\
\hline $\begin{array}{l}\text { No intermittent } \\
\text { peak exposure }\end{array}$ & 15 & 19 & $1-87$ & 0.0 & $0.0-0.2$ & - & 0 & 0.03 & $0-0.13$ & - & 0 \\
\hline Group 2 & 32 & 37 & $1-1064$ & 0.2 & $0.0-20$ & 11 & 34 & 0.17 & $0-1.5$ & 14 & 47 \\
\hline Group 3 & 26 & 23 & $0-257$ & 0.1 & $0.0-8$ & 5 & 19 & 0.15 & $0-1.6$ & 11 & 42 \\
\hline Referents & 54 & 28 & $0-827$ & 0.0 & $0.0-0.2$ & . & . & 0.02 & $0-0.2$ & $\cdot$ & . \\
\hline
\end{tabular}


significantly higher IgG levels than the IgE negative workers $(\mathrm{P}=0.0001)$. However, six workers were positive for IgE antibodies but negative for IgG antibodies.

\section{Discussion}

A prevalence of $24 \%$ of RAST positive workers was found in a group of 95 workers from two plants handling epoxy resins with HHPA as a hardener. IgE sensitization was found at very low exposure levels. However, the interpretation of the results from crosssectional studies must be handled carefully. The number of sensitized workers may mainly reflect previous exposures. In this study the workers were investigated in 1989 and 1990, and no measurements of the exposure levels were performed before 1989 . However, there is no information indicating a drastic decrease in anhydride exposure as a consequence of extensive preventive measures during the four years preceding the investigation, the period that was possible to survey and which corresponded to the median time of exposure for the studied workers and the specific RAST positive workers. Certainly, it can still be assumed that there has been continuous improvement in the work environment once the processes have been established and have reached their full capacity. The most heavily exposed workers were those exposed to vapor from uncured resin in casting and curing operations (mainly group 3 ). As the main exposure originates from leakages from the curing ovens, it is also the exposure of these workers that, above all, may have been underestimated. Workers in groups 1 and 2, however, mainly worked in adjacent departments with a more limited direct contact with uncured resin. Thus their exposure levels were not likely to be very different from the levels at the time of the investigation. In addition, eight of the positive workers were employed in 1988 or later. Three workers were positive after less than one year's exposure. On the other hand, a healthy worker selection may also have flattened or even reversed the exposure-response relationship. However, we have no information suggesting that a considerable number of persons had left work because of reactions to the anhydrides, at least not in the most exposed area.

The specificity and sensitivity of the RAST test has earlier been studied on sera from the present investigation (16). The RAST and ELISA readings were low and precise for the unexposed referents (group 0) and external referents. The RAST readings were low even in the presence of high titers of total IgE antibodies $\left(827 \mathrm{kU} \cdot \mathrm{l}^{-1}\right)$.

It is notable that there was no significant difference in either the IgE HHPA-HSA levels or the number of positives in groups $1-3$. Cross-sectional studies have obvious limitations for studies on exposure-response relationships, as the results may be affected by workers having left their jobs because of discomfort or illness ("healthy worker selection"). Workers would probably leave the high exposure area and thus "flatten" an exposure-response curve. In addition to healthy-worker selection, the exposureresponse relationship may have been "flattened" by the in vivo blocking of antibodies $(17,18)$, as well as by hyposensitization in the most exposed groups $(19,20)$. It is also possible that persons liable to IgE formation may be sensitized already at low exposure levels. An interesting point is that five workers in group 1 with intermittent peak exposures to HHPA had a positive RAST, while no one was positive in the other groups. The peak exposures lasted for only a few minutes a day and had only a small effect on the time-weighted average levels. However, the intermittently exposed workers had a longer time of exposure. Some of the workers in group 2 also spend most of their time in premises with low exposure intensities and obtained their exposure by irregular visits to high exposure areas. Another difference is the more pronounced exposure to MHHPA in group 2. There has, so far, been no evidence suggesting MHHPA as a more potent IgE sensitizer than HHPA. Only a few cases of IgE-sensitized workers exposed to MHHPA have earlier been reported (21). However, as $65 \%$ of the workers in group 2 had exposure to MHHPA (MHHPA level about $30 \%$ of the total anhydride level) MHHPA may be a potent sensitizer. A major problem that also may have affected the shape of the exposure-response curve is a possible misclassification of the workers into the different exposure categories. In the first place, it may be presumed, from the exposure data, that some of the workers in group 2 might as well belong to group 3 . These workers had measured exposure levels of $>50 \mu \mathrm{g} \cdot \mathrm{m}^{-3}$ during work but were categorized into group 2 because their work was not full-time.

There are conflicting reports on the effect of atopy and smoking on the formation of $\operatorname{IgE}$ antibodies in workers exposed to acid anhydride $(10,11,22)$. In this study no effects of either atopy or smoking habits were found on the findings of IgE positives. Data are given in this report only on antibodies to HHPA-HSA also if the workers have been exposed to MHHPA as well. However, data from this study, as well as from another study (16), show a very close correlation between MHHPA and HHPA in RAST and skin prick tests, probably due to cross-reactivity.

The IgG HHPA-HSA levels were significantly increased in groups 2 and 3 in comparison with the other groups. The results suggest that IgG antibodies are an indication of exposure; this finding corresponds to those of earlier studies on acid anhydrides (811 ) and diisocyanates (23). The prevalence of workers with specific IgE and IgG antibodies to HHPAHSA in this study is lower than the corresponding finding by Moller et al (8) (44 and 41\%) in HHPAexposed workers, but the exposure intensity was much higher in the latter group $\left(0.6-8 \mu \mathrm{g} \cdot \mathrm{m}^{-3}\right)$. In addition, there was some kind of self-selection in the 
Moller group. The present results are comparable with those found in a study on MTHPA-exposed workers at similar exposure levels (10). A correlation between exposure and $\operatorname{IgE}$ antibodies was more evident in the MTHPA group, but the exposure-response curve for the formation of IgG antibodies in the HHPA group seemed to be more accentuated than the results from the MTHPA-exposed workers. The prevalence of workers with specific $\mathrm{IgE}$ antibodies was higher than what has been found in workers exposed to phthalic anhydride (PA) and trimellitic anhydride (TMA) at higher exposure levels $(9,24,25)$. Among workers exposed to tetrachlorophthalic anhydride (TCPA), $8-31 \%$ have been found positive in the RAST $(11,22)$. The exposure intensity in the former study was $0.21-0.39 \mu \mathrm{g} \cdot \mathrm{m}^{-3}$, and the prevalence of $\operatorname{IgE}$ antibodies was highest in the most exposed group $(54 \%)$. Thus HHPA, MTHPA, and TCPA seem to be more potent IgE sensitizers than PA and TMA.

The average air concentrations of HHPA having caused $\operatorname{IgE}$ sensitization in this study were considerably lower than what has been reported on other anhydrides except MTHPA, and also lower than the occupational exposure limits for organic acid anhydrides in different countries, as reported by Keskinen (7). The results of this investigation suggest that permissible average exposure levels for HHPA should not be above $10-20 \mu \mathrm{g} \cdot \mathrm{m}^{-3}$ and that shorttime peak exposures may have a great impact on the production of IgE antibodies. Thus ceiling values are very important for protection against IgE sensitization. This finding emphasizes a need for good methods for monitoring peak exposures and also places great emphasis on the importance of extensive preventive measures in the work environment.

\section{Acknowledgments}

The project was supported by grants from the Swedish Work Environment Fund (AMFO 91-0152) and the Medical Faculty at Lund University.

We thank Ms I Bensryd for her valuable help with the collection of blood samples and information on the workers and B Ståhlbom, MSc, for his assistance with the air sampling. We also thank the staff and personnel of the involved companies and the company health services for their generous cooperation.

\section{References}

1. Fabbri LM. Asthma - what are the important experiments?: occupational factors. Am Rev Respir Dis 1988;138:737-8.

2. Newman-Taylor A, Tee RM. Environmental and occupational asthma: exposure assessment. Chest 1990; 98 suppl 5:2095.

3. Reed CE. Clinical management when the environment can be changed. Chest 1990;98 suppl 5:216S.

4. Special Interest Group on Occupational Allergy of the British Society of Allergy and Clinical Immunology.
Special report: priorities for understanding and managing occupational allergy: a Delphi consensus. Clin Exp Allergy 1993;23:634-7.

5. Hagmar L, Nielsen J, Skerfving S. Clinical features and epidemiology of occupational obstructive respiratory disease caused by small molecular weight organic chemicals. Monogr Allergy 1987;21:42-58.

6. Venables KM. Low molecular weight chemicals, hypersensitivity, and direct toxicity: the acid anhydrides. Br J Ind Med 1989;46:222-32.

7. Keskinen H. Nordic Expert Group for Documentation of Occupational Exposure Limits. 92. Organic acid anhydrides. Stockholm: Arbetarskyddsverket, 1990. Arbete och hälsa 1990;48.

8. Moller DR, Gallagher IS, Bernstein DI, Wilcox TG, Burroughs HE, Bernstein IL. Detection of IgE mediated respiratory sensitization in workers exposed to hexahydrophthalic anhydride. J Allergy Clin Immunol 1985;75:663-72.

9. Nielsen J, Welinder H, Schütz A, Skerfving S. Specific serum antibodies against phthalic anhydride in occupationally exposed subjects. J Allergy Clin Immunol 1988;82:126-33.

10. Welinder H, Nielsen J, Gustavsson C, Bensryd I. Specific antibodies to methyltetrahydrophthalic anhydride in exposed workers. Clin Exp Allergy 1990;20:63945.

11. Liss GM, Bernstein D, Genesove L, Roos JO, Lim J. Assessment of risk factors for IgE-mediated sensitization to tetrachlorophthalic anhydride. J Allergy Clin Immunol 1993;92:237-47.

12. Zeiss CR, Patterson R, Pruzansky JJ, Miller MM, Rosenberg M, Levitz D. Trimellitic anhydride (TMA) induced airway syndromes: clinical and immunologic studies. J Allergy Clin Immunol 1977;60:96-103.

13. Nielsen J, Welinder H, Horstman V, Skerfving S. Allergy to methyltetrahydrophthalic anhydride in epoxy resin workers. Br J Ind Med 1992;49:769-75.

14. Jönsson B, Welinder $H$, Skarping $G$. Determination of hexahydrophthalic anhydride in air using gas chromatography. J Chromatogr 1991;558:247-56.

15. Welinder H, Gustavsson C. Methyltetrahydrophthalic anhydride in air - sampling and analysis. Ann Occup Hyg 1992;36:189-97.

16. Welinder H, Nielsen J. Immunologic tests of specific antibodies to organic acid anhydrides. Allergy 1991; 46:601-9.

17. Bernstein DI, Zeiss CR, Wolkonsky P, Levitz D, Roberts $M$, Patterson $R$. The relationship of total serum IgE and blocking antibody in trimellitic-induced occupational asthma. J Allergy Clin Immunol 1983;72: 714-19.

18. Biagini RE, Bernstein DI, Gallagher JS, Moorman WJ, Knecht EA, Smallwood AW. Immune responses of cynomolgus monkeys to phthalic anhydride. J Allergy Clin Immunol 1988;82:23-9.

19. Leach CL, Hatoum NS, Zeiss CR, Garvin PJ. Immunologic tolerance in rats during 13 weeks of inhalation exposure to trimellitic anhydride. Fundam Appl Toxicol 1989;12:519-29.

20. Björkstén B, Turner K. Regulation of IgE antibody formation in the airways. In: Mygind N, Pipkorn U, Dahl R, editors. Rhinitis and asthma: similarities and differences. Copenhagen: Munksgaard, 1990.

21. Keskinen $H$, Nordman $H$, Tupasela $O$, Vaheri E, Pfäffli $\mathrm{P}$, Sarjanen M. Methylhexahydrophthalic anhydride (MHHPA) induced asthma and rhinitis. N Engl Reg Allergy Proc 1988;9:397.

22. Venables KM, Topping MD, Howe W, Luczynska CM, Hawkins R, Newman Taylor AJ. Interaction of smoking and atopy in producing specific IgE antibody against a hapten protein conjugate. Br Med J 1985; 290:201-4.

23. Seldén AI, Belin L, Wass U. Isocyanate exposure and 
hypersensitivity pneumonitis - report of a probable case and prevalence of specific immunoglobulin $G$ antibodies among exposed individuals. Scand J Work Environ Health 1989;15:234-7.

24. Sale SR, Roach DE, Zeiss CR, Patterson R. Clinical and immunologic correlations in trimellitic anhydride airway syndromes. J Allergy Clin Immunol 1981;68: $188-93$.
25. Zeiss CR, Wolkonsky P, Chacon R, Tuntland PA, Levitz D, Pruzansky JJ, et al. Syndromes in workers exposed to trimellitic anhydride: a longitudinal clinical and immunologic study. Ann Intern Med 1983;98:812.

Received for publication: 17 December 1993 